\title{
Pendampingan Hidroponik 55 untuk Tumbuh Kembang dengan Usaha Produksi Sayur Sehat dan Menjadi Tujuan Eco-Eduwisata di Cupak Tangah, Padang
}

\author{
Fitri Mailani', Donny Eros ${ }^{2}$, Jauharry ${ }^{3}$, dan Mulyanti Roberto Muliantino ${ }^{4}$ \\ ${ }_{1}^{1}$ Fakultas Keperawatan, Universitas Andalas, Kampus Limau Manis, Padang, 25163. Indonesia \\ ${ }^{2}$ Fakultas Ilmu Budaya, Universitas Andalas, Kampus Limau Manis, Padang, 25163. Indonesia \\ ${ }^{3}$ Fakultas Ekonomi, Universitas Andalas, Kampus Limau Manis, Padang, 25163. Indonesia \\ E-mail: fitrimailani22@gmail.com
}

Keywords:

assistance,

hidroponic,

healthy

vegetables, eco-

edutourism

Kata Kunci: pendampingan, hidroponik, sayuran sehat, eco-eduwisata

\begin{abstract}
The advantages of this hydroponic vegetable product are that it is free of chemical pesticides; the taste of vegetables is crunchy and sweet, clean, environmentally friendly, and affordable. However, the public's knowledge and understanding regarding hydroponic vegetables is still very little and not evenly distributed in all circles, so that marketing is only limited to certain groups. This service aims to assist and assist Hydroponics 55 partners in producing healthy vegetables and developing into an Ecotourism area. This service activity is planned to last for 3 years (2021-2024). With the following activity plans: 1) designing a green-house in agricultural areas, 2) increasing online and offline promotion and education, 3) submitting a proposal for collaboration with restaurants, cafes, hospitals and supermarkets in the city of Padang, 4) developing Hydroponic 55 businesses, in processing healthy food derived from hydroponic vegetables, 5) developing agricultural areas into Eco-tourism areas. Activities that have been carried out this year include making educational posters and promoting hydroponic vegetables and distributing them through social media, conducting FGDs with stakeholders, inviting speakers regarding greenhouse preparation and providing knowledge dissemination related to marketing tricks and eco-tourism concepts and facilitating partners in develop business licenses in processing healthy food products. The results of this activity are in the form of educational and promotional posters, proposals for making green-houses, proposals for developing healthy food processing and proposals for developing eco-tourism areas.
\end{abstract}

\section{ABSTRAK}

Keunggulan dari produk sayuran hidroponik ini adalah bebas pestisida kimia, rasa sayur renyah dan manis, bersih, ramah lingkungan, dan harga terjangkau. Namun pengetahuan dan pemahaman masyarakat terkait dengan sayuran hidroponik ini masih sangat rendah dan tidak merata disemua kalangan, sehingga pemasaran hanya terbatas pada kalangan tertentu saja. Pengabdian ini bertujuan untuk mendampingi dan membantu mitra Hidroponik 55 dalam memproduksi sayuran sehat dan berkembang menjadi kawasan Eco-Eduwisata. Kegiatan pengabdian ini direncanakan akan berlangsung selama 3 tahun (2021-2024). Dengan rencana kegiatan sebagai berikut: 1) merancang pembuatan green house di kawasan pertanian, 2) meningkatkan promosi dan edukasi secara online dan offline, 3) mengajukan proposal kerja sama dengan restoran, kafe, rumah sakit, dan swalayan di kota Padang, 4) mengembangkan usaha Hidroponik 55, dalam mengolah makanan sehat yang berasal dari sayuran hidroponik, 5) mengembangkan kawasan pertanian menjadi kawasan Eco-Eduwisata. Kegiatan yang telah dilakukan pada tahun berjalan 
ini yaitu membuat poster edukasi dan promosi sayuran hidroponik dan menyebarkan melalui media sosial, melakukan FGD dengan stakeholder, mengundang pemateri terkait persiapan green house dan memberikan desiminasi ilmu terkait dengan trik pemasaran dan konsep eco-eduwisata dan memfasilitasi mitra dalam mengembangkan ijin usaha dalam mengolah produk makanan sehat. Hasil kegiatan ini adalah berupa poster edukasi dan promosi, proposal pembutan green house, proposal pengembangan pengolahan makanan sehat dan proposal pengembangan kawasan eco-eduwisata.

\section{PENDAHULUAN}

Sayuran hidroponik adalah sayuran yang tumbuh dengan bantuan cairan yang mengandung mineral yang diperlukan oleh sayuran untuk tumbuh. Berbeda dengan sayuran lainnya yang membutuhkan tanah untuk tumbuh, tanaman hidroponik hanya membutuhkan air bermineral untuk tumbuh. Air yang digunakan untuk menanam sayuran ini pun bisa didaur ulang. Keunggulan dari produk sayuran hidroponik ini adalah bebas pestisida kimia, rasa sayur renyah dan manis, bersih, ramah lingkungan, dan harga terjangkau (Roidah, 2015). Namun pengetahuan dan pemahaman masyarakat terkait dengan sayuran hidroponik ini masih sangat rendah dan tidak merata oleh semua kalangan.

Hidroponik 55 merupakan usaha sayuran hidroponik yang memproduksi sayuran sehat bebas pestisida kimia diantaranya Sawi Pakchoy, sawi Chaisin, Kangkung, Daun Mint dan Selada. Hidroponik 55 didirikan oleh Brian Permana, SP (alumni Fakultas Pertanian UNAND) pada tahun 2017 di Dharmasraya dengan nama awal Kakek Hidroponik. Setelah berjalan lebih kurang 1 tahun Kakek Hidroponik mengikuti program PWMP (Penumbuhan Wirausahawan Muda Pertanian) di Kampus Pertanian Unand dan lolos seleksi. Pada bulan Oktober 2018 resmi Kakek Hidroponik berubah nama menjadi Hidroponik 55. Lokasi Hidroponik 55 saat ini di Jalan Sungai Balang Cupak Tangah, Kecamatan Pauh, Kota Padang, lokasi berada tepat di belakang sekretariat Pasar Rabu Tani. Seiring berjalannya waktu, ditemukan beberapa kendala yang dihadapi oleh Hidroponik 55 dalam mengembangkan usahanya. Ditambah dengan kondisi pandemi Covid-19 yang mempengaruhi proses pemasaran dan penjualan sayuran yang diproduksi yang mengakibatkan omset menurun.

Setelah berdiskusi dengan mitra, ada beberapa permasalahan yang prioritas untuk diselesaikan yaitu ketidakpastian pasar dalam menampung hasil produksi dan keterbatasan pasar yang terbentuk baru untuk masyarakat menengah ke atas saja. Yang kedua adalah masalah hama yang menyebabkan kualitas sayur yang dihasilkan menurun. Dan yang ketiga adalah mengembangkan usaha hidroponik 55 seperti mengolah makanan sehat dan menjadi kawasan Eco-Eduwisata. Kegiatan pengabdian ini direncanakan akan berlangsung selama 3 tahun (20212024). Dengan rencana kegiatan sebagai berikut: 1) merancang pembuatan green house di kawasan pertanian, 2) meningkatkan promosi dan edukasi secara online dan offline, 3) mengajukan proposal kerja sama dengan restoran, kafe, rumah sakit, dan swalayan di kota Padang, 4) mengembangkan usaha Hidroponik 55 dalam mengolah makanan sehat yang berasal dari sayuran hidroponik, 5) mengembangkan kawasan pertanian menjadi kawasan EcoEduwisata. Tujuan akhir kegiatan ini adalah meningkatnya omset penjualan Hidroponik 55 dan memperluas usaha Hidroponik 55 menjadi usaha pengolahan makanan sehat dan kawasan pertanian Hidroponik 55 menjadi salah satu kawasan Eco-Eduwisata di Kota Padang. 


\section{METODE}

Metode pelaksanaan kegiatan pengabdian ini terlihat dari usaha untuk memberikan solusi terhadap permasalahan yang dihadapi oleh mitra yaitu sebagai berikut:

a. Melakukan edukasi kepada masyarakat terkait kualitas sayuran hidroponik secara online yang disebarkan melalui media sosial. Kegiatan ini dimulai dengan membuat poster edukasi dan promosi terkait dengan perkenalan dengan sistem pertanian hidroponik, prinsip, manfaat, keunggulan dan jenis sayuran yang tersedia diHidroponik 55.

b. Meningkatkan kualitas kemasan dengan membranding dengan logo menarik.

c. Memperluas pemasaran/penjualan hasil panen dengan membuat proposal kerjasama yang akan ditawarkan ke beberapa lembaga seperti rumah sakit, swalayan, restoran dan kafe dalam memasok sayuran. Kegiatan ini dimulai dengan kegiatan FGD dengan stakeholder dengan menghadirkan ketua KMDM dan direktur Pasar Rabu Tani untuk mencarikan solusi pemasaran dan pengembangan mitra.

d. Perencanaan pembuatan green house yang memadai di area pertanian untuk mengantisipasi banyak hama tanaman, penyakit tanaman dan iklim yang ekstrim yang bisa menyebabkan gagal panen. Kegiatan ini sudah dimulai dengan mengundang Arif Abdul Putra, yang merupakan penggiat hidroponik dan telah berhasil membuat green house sendiri dikawasan pertanian miliknya, untuk membantu mitra dalam persiapan pembangunan green house.

e. Mengembangkan kawasan pertanian Hidroponik 55 menjadi salah satu kawasan EcoEduwisata di Kota Padang. Kegiatan ini diawali dengan diseminasi ilmu terkait dengan konsep kawasan eco-eduwisata dan materi disampaikan langsung oleh tim pelaksana pengabdian yaitu Bapak Donny Eros, SS, MA yang sudah berpengalaman mendampingi pengembangan daerah wisata di Sumatera Barat. Kegiatan selanjutnya penyampaian materi mengenai pemasaran sayuran hidroponik oleh tim pelaksana yaitu Bapak Jauharry, SE., MM.

\section{HASIL DAN PEMBAHASAN}

Kegiatan pengabdian ini dimulai pada tanggal 3 Desember sampai dengan 15 Desember 2020. Kegiatan pengabdian ini direncanakan dilaksanakan selama 3 tahun (2021-2024) dengan target pencapaian pada tahun berjalan pada saat ini adalah kesepakatan dengan mitra untuk mengembangkan usaha Hidroponik 55 agar lebih unggul dalam produksi sayuran sehat dan mengembangkan usaha untuk pengolahan makanan sehat dan menjadi kawasan Eco-Eduwisata. Hasil Focus Group Discussion (FGD) terkait permasalahan utama yang akan diselesaikan selama pengabdian ini berlangsung selama tiga tahun kedepan yaitu: 1) merancang pembuatan greenhouse di kawasan pertanian, 2) meningkatkan promosi dan edukasi secara online dan offline, 3) mengajukan proposal kerja sama dengan restoran, kafe, rumah sakit, dan swalayan di kota Padang, 4) mengembangkan usaha Hidroponik 55 dalam mengolah makanan sehat yang berasal dari sayuran hidroponik, 5) mengembangkan kawasan pertanian menjadi kawasan EcoEduwisata. Sebagai langkah awal kegiatan adalah melakukan FGD dengan stakeholder terkait dengan solusi terhadap permasalahan yang dihadapi oleh mitra dengan mengundang Bapak Virtuous Setyaka, S.IP, M.Si selaku ketua Koperasi Pemasaran Mandiri dan Merdeka (KMDM) dan Ibu Eli Ratni, S.Pt, MP sebagai direktur Pasar Rabu Tani. 


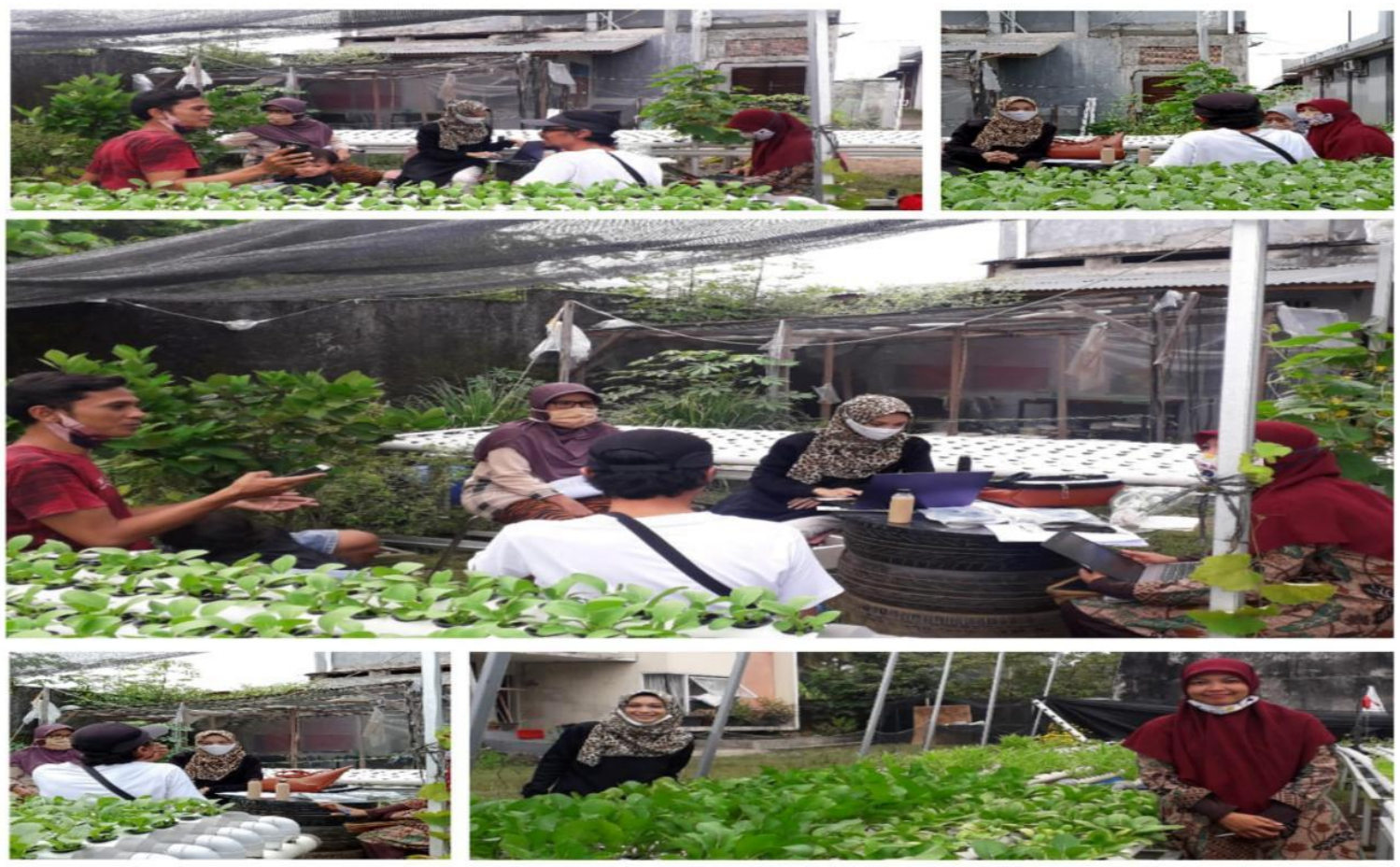

Gambar 1. FGD dengan mitra dan stake holder

Kegiatan selanjutnya, Kamis 10 Desember 2020 tim pengabdian mengundang Arif Abdul Putra, yang merupakan penggiat hidroponik dan telah berhasil membuat green house sendiri dikawasan pertanian miliknya. Dalam hal ini, mitra dibimbing untuk menyiapkan pembuatan green house, materi dan bahan apa saja yang bisa digunakan dan rancangan anggaran biaya yang dibutuhkan.

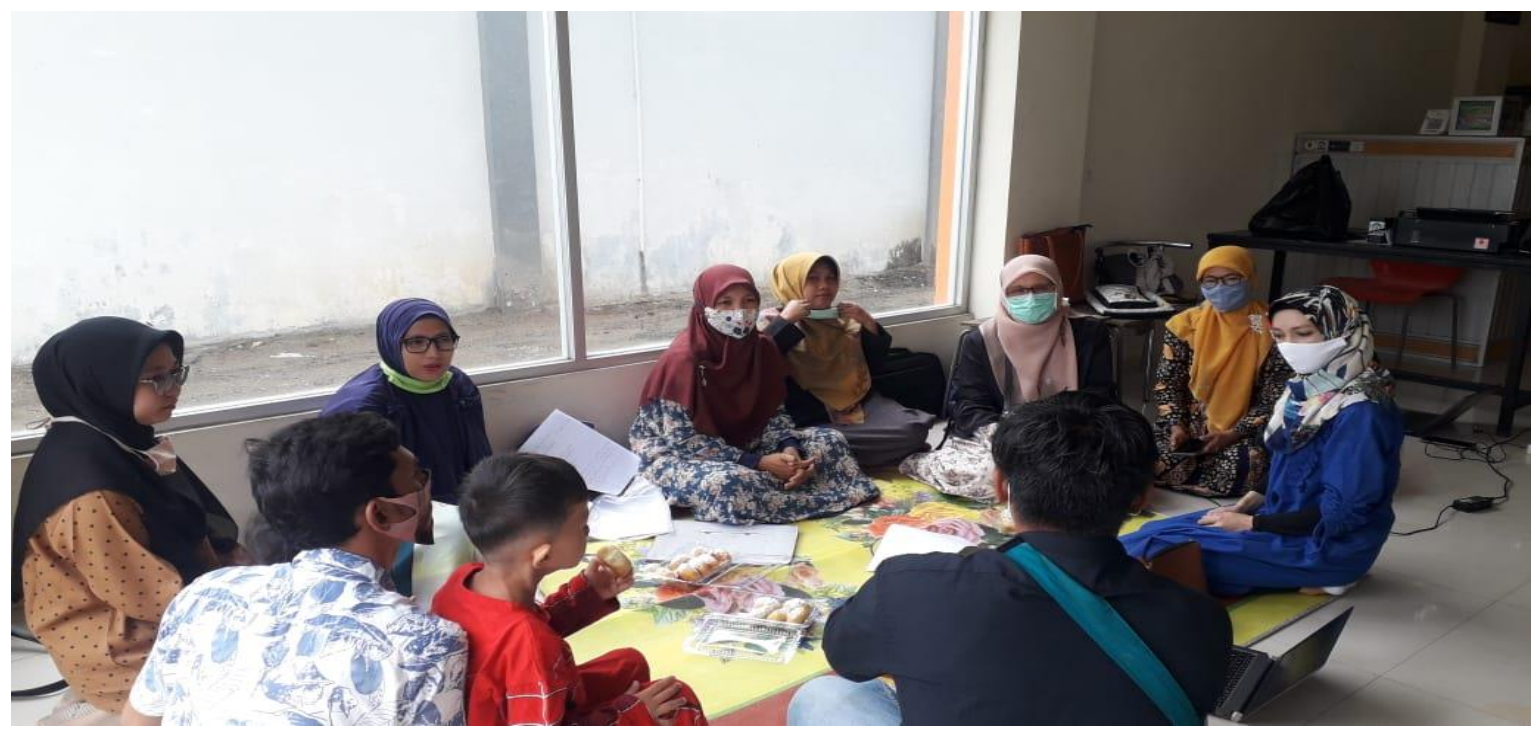

Gambar 2. Kegiatan Diskusi Persiapan Green House 


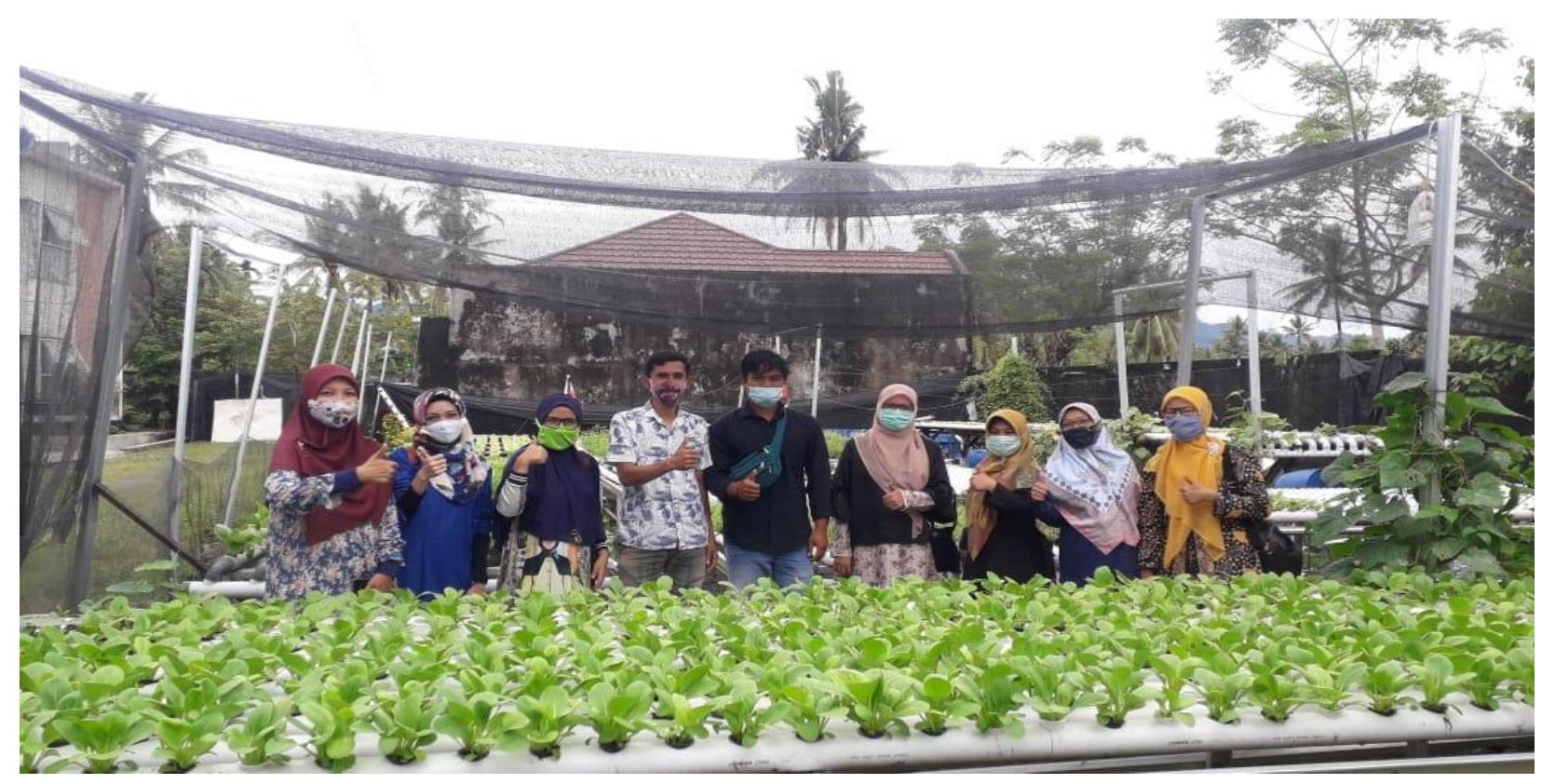

Gambar 3. Meninjau Lokasi Persiapan Pembuatan Green House

Kegiatan selanjutnya adalah diseminasi ilmu terkait persiapan Hidroponik 55 menjadi kawasan Eco-Eduwisata hidroponik dilaksanakan pada tanggal 15 Desember 2020 melalui zoom meeting dan materi disampaikan langsung oleh tim pelaksana pengabdian yaitu Bapak Donny Eros, SS, MA yang sudah berpengalaman mendampingi pengembangan daerah wisata di Sumatera Barat. Kegiatan FGD diakhiri dengan penyampaian materi mengenai pemasaran sayuran hidroponik oleh Bapak Jauharry, SE, MM.

Tim pelaksana pengabdian bekerja sama dengan designer profesional untuk membuat poster edukasi dan promosi terkait dengan pengenalan metode hidroponik, manfaat, media, jenis sayuran dan produk apa saja yang tersedia di Hidroponik 55. Poster yang telah dirancang disebarkan melalui akun media sosial. Media promosi melalui poster yang dibagikan di media sosial diharapkan mampu meningkatkan pemahaman masyarakat. Promosi berbasis edukasi yang disebar melalui media sosial diharapkan mampu menyentuh seluruh kalangan dan meningkatkan pemahaman akan pentingnya mengkonsumsi sayuran sehat.

Pengembangan kawasan eco-eduwisata pada lahan pertanian Hidroponik 55 masih membutuhkan perancanaan yang matang dan membutuhkan waktu yang panjang. Terkait kawasan pertanian yang berada di tengah kota dan luas wilayah yang sempit. Namun diharapkan Hidroponik 55 tidak hanya mampu memproduksi sayuran tetapi menjadi tempat meningkatkan pengetahuan di bidang hidroponik. Pendiri Hidroponik 55 yang merupakan sarjana pertanian dan merupakan instruktur petani hidroponik diharapkan mampu membuka peluang edu wisata bagi masyarakat. Pengembangan menjadi pusat pengolahan makanan sehat yang berbahan utama sayuran hidroponik menjadi daya tarik untuk berkunjung ke kawasan pertanian Hidroponik 55. Menurut Suyastiri (2012), pelaksanaan konsep edu wisata akan dapat meningkatkan kesejahteraan petani. Strategi pertama untuk mengembangkan kawasan ecoeduwisata dalam jangka pendek seharusnya memperhitungkan kebutuhan infrastuktur dan keamanan untuk wisatawan, serta adanya kerjasama yang efektif dengan biro perjalanan untuk mempromosikan tempat-tempat pariwisata baru (Catalino dan Lizardo, 2004). Melalui pengembangan agrowisata yang menonjolkan budaya lokal dalam memanfaatkan lahan, pendapatan petani diharapkan dapat ditingkatkan dan sekaligus melestarikan sumber daya lahan, serta memelihara budaya maupun teknologi lokal yang umumnya sesuai dengan lingkungan kondisi alaminya (Sanjaya, 2013). 


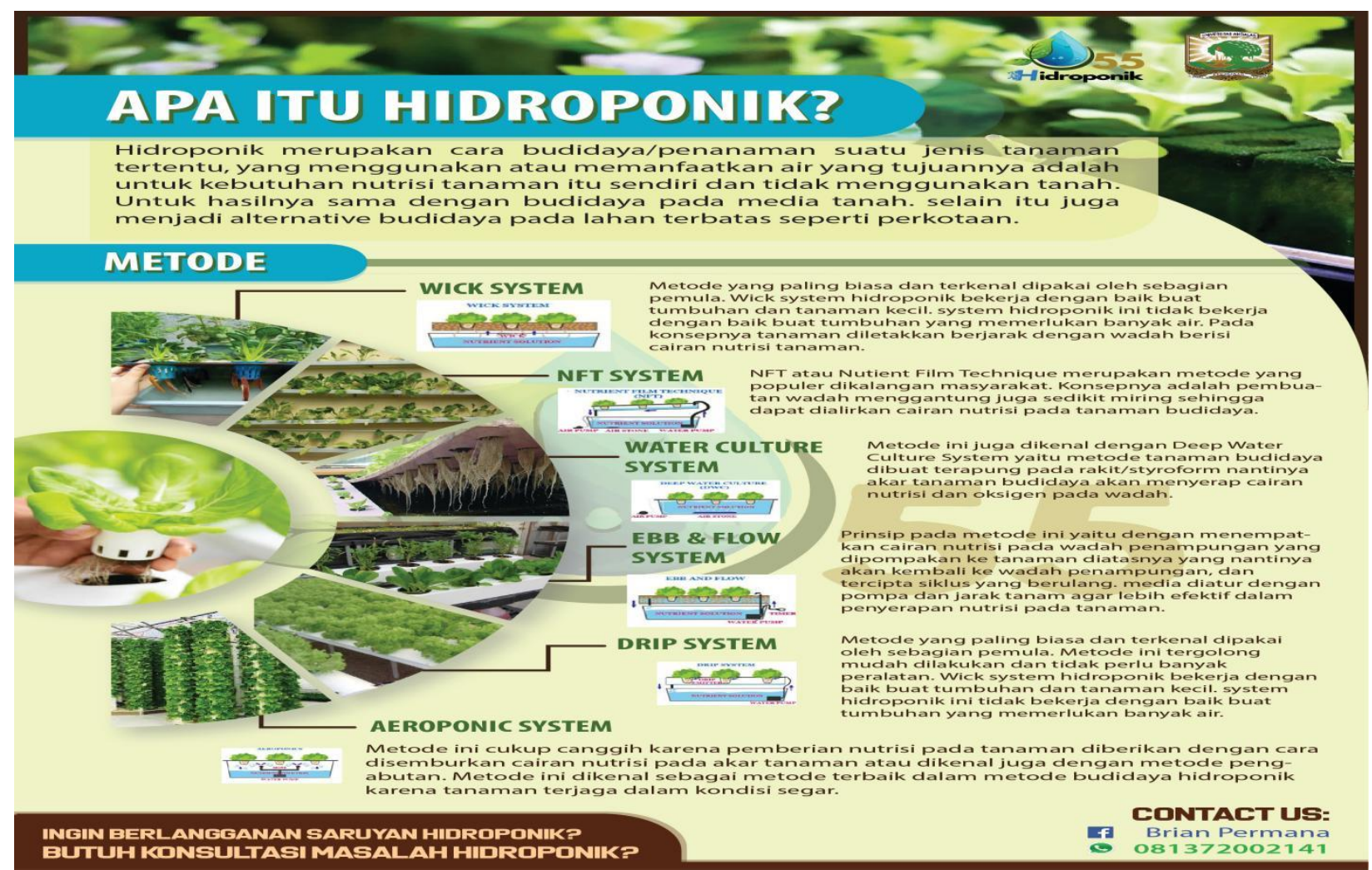

Gambar 4. Poster Edukasi Pengenalan Hidroponik

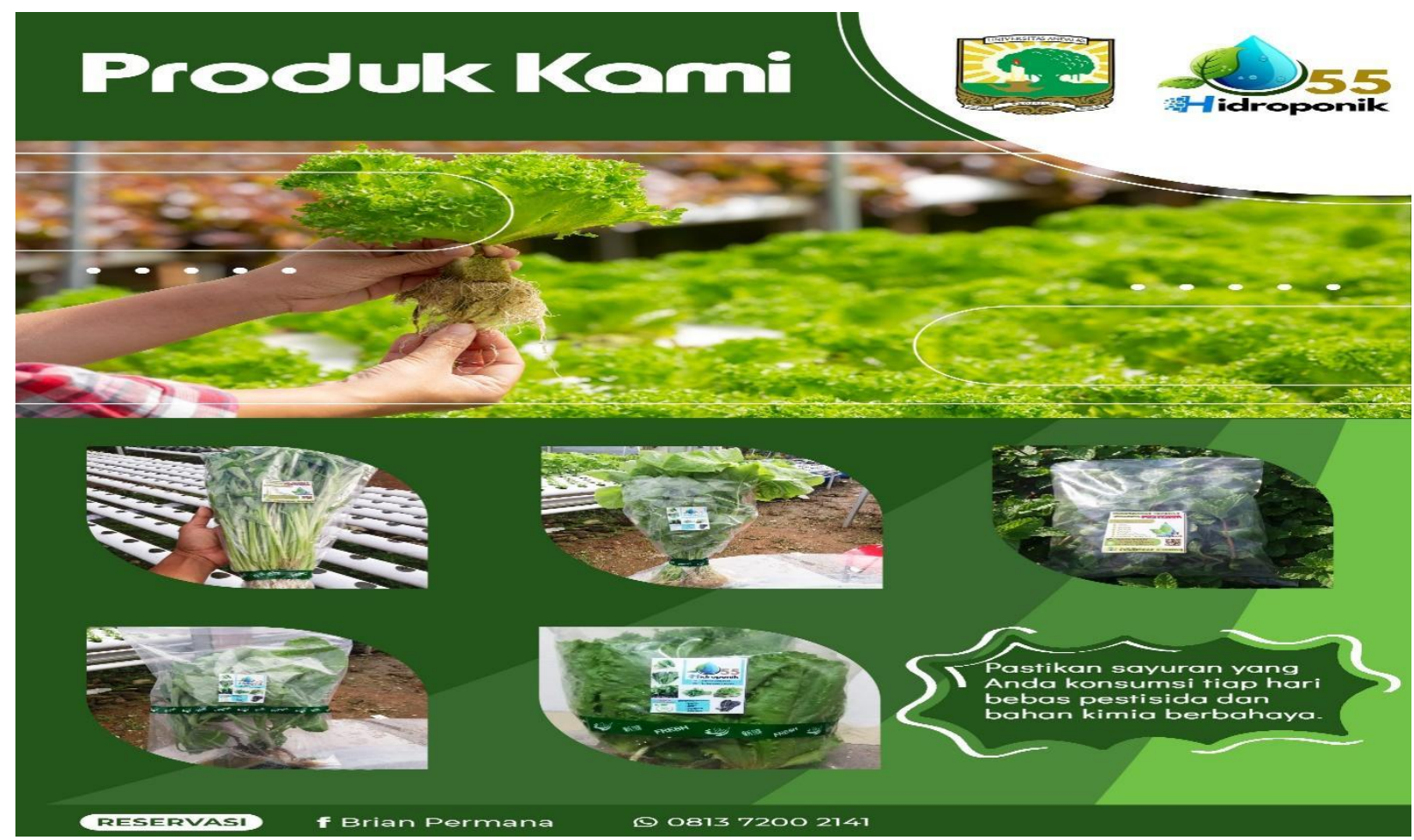

Gambar 5. Poster Promosi Sayuran Hidroponik 55 
Semakin maraknya konsep wisata yang berbau pertanian yang ditawarkan bagi umum membuka peluang baru dalam industri pertanian. Hal ini dapat dijadikan salah satu metode dalam diseminasi inovasi dan teknologi khususnya dalam dunia seputar pertanian. Secara umum, selain menjadi pilihan masyarakat dalam mengisi waktu libur, manfaat dari konsep agrowisata ini antara lain: 1. Sebagai wahana untuk mendiseminasikan berbagai teknologi pertanian kepada masyarakat secara umum, 2. Sebagai kegiatan dalam rangka memanfaatkan dan melestarikan lingkungan sekitar, 3. Meningkatkan pendapatan petani dan membuka lapangan pekerjaan bagi masyarakat sekitar, 4. Menambah nilai estetika pada lingkungan sekitar, dan 5. Sebagai wahana edukasi dan merangsang kegiatan ilmiah kawasan perkotaan. Oleh karena itu, penting adanya wahana edukasi seputar dunia pertanian untuk mengantisipasi minimnya pengetahuan masyarakat di bidang pertanian. Selain itu, telah terjadinya perubahan gaya hidup masyarakat perkotaan untuk kembali ke alam semakin mengilhami masyarakat untuk lebih peduli kepada alam.

\section{KESIMPULAN}

Pendampingan mitra usaha berkembang Hidroponik 55 dilakukan melalui beberapa tahapan kegiatan seperti edukasi dan promosi secara online melalui media sosial, dan pengembangan kawasan pertanian selain memproduksi sayuran sehat tetapi juga menghasilkan makanan produk olahan dari bahan dasar sayuran. Pengembangan kawasan hidroponik 55 menjadi kawasan eco-eduwisata masih berada di tahap perencanaan dengan langkah awal pembenahan tata letak lahan pertanian dan persiapan pembuatan green house. Peningkatan pemasaran sudah dimulai dengan membuat proposal penawaran dan kerjasama, dengan tujuan meningkatkan omset mitra dan peningkatan kerjasama dalam pemasaran sayuran hidroponik. Kegiatan ini bermanfaat terhadap pengembangan usaha mitra dan menambah pengetahuan masyarakat tentang pentingya mengkonsumsi sayur sehat.

\section{UCAPAN TERIMA KASIH}

Terima kasih kepada LPPM Universitas Andalas sebagai penyandang dana program pengabdian masyarakat berkelanjutan skim program kemitraan masyarakat membantu usaha berkembang. Selanjutnya terima kasih kepada tim KMDM dan Pasar Rabu Tani yang membantu memfasilitasi kegiatan pengabdian kepada masyarakat untuk Hidroponik 55 sehingga kegiatan ini terlaksana.

\section{DAFTAR PUSTAKA}

Catalino, Alejandro Herrera., and Magdalena Lizardo. 2004. Agriculture, Environtmental Services and AgroTourism in Dominican Republic. , Vol.1 No.1 2004, pp.109.

Hendra, H. A., \& Andoko, A. (2014). Bertanam sayuran hidroponik ala paktani hydrofarm. AgroMedia.

Nasihien, R. D., Wulandari, D. A. R., Zacoeb, A., \& Setiawan, M. I. (2017). Teknologi Portable Inflated Greenhouse Sebagai Fasilitas Pendukung Peningkatan Ketahanan Pangan Dan Pertanian. 
Roidah, I. S. (2015). Pemanfaatan lahan dengan menggunakan sistem hidroponik. Jurnal Bonorowo, 1(2), 43-49.

Rosliani, R., \& Sumarni, N. (2005). Budidaya tanaman sayuran dengan sistem hidroponik.

Sanjaya, I Gede Arya., Cocorda, G.A.S., dan I Nyoman, G.A., 2013. Studi Potensi Subak Renon di Denpasar Selatan untuk Pengembangan Agrowisata. Vol. 2 No.1. Januari 2013.

Suyastiri, Ni Made. 2012. Pemberdayaan Subak melalui "Green Tourism" Mendukung Keberlanjutan Pembangunan Pertanian di Bali. Vol.8 No.2 Februari 2012. Hlm.168-173.

Telaumbanua, M., Purwantana, B., Sutiarso, L., \& Falah, M. A. F. (2016). Studi pola pertumbuhan tanaman sawi (Brassica rapa var. parachinensis L.) hidroponik di dalam greenhouse terkontrol. agriTECH, 36(1), 104-110.

Perkotaan (Urban Farming). Jurnal Darussalam: Jurnal Pendidikan, Komunikasi dan Pemikiran Hukum Islam, 9(1), 161-183. 